\title{
Effect of Music Therapy in Improving Non-verbal Communication Ability in Autism Children
}

\author{
Intan K Dewi, Setyowati BU, I Made Widagda, Dwi Pudjonarko \\ Department of Physical Medicine and Rehabilitation, Faculty of Medicine University of Diponegoro, \\ Semarang, Indonesia.
}

\begin{abstract}
Objectives: To observe the effect of music therapy in non-verbal communication ability of autism children.

Methods : Study design was pre and post test design. Nineteen subjects - 9 was mild-moderate autism ( 1 girl and 8 boys ) and 10 was severe autism ( 2 girls and 8 boys), age was between 3-15 years- were applied music therapy by listening 3 children songs from tape recorder,for 15 minutes daily. Childhood Autism Rating Scale (CARS) was conducted to assess severity of autism (mild, moderate, severe) and Early Social Communication Scale (ESCS) to assess ability of non verbal communication with IJA (Initial Joint Attention) and Responding to Joint Attention (RJA). Descriptive statistic and homogeneity test was performed to evaluate the change on CARS and ESCS score in pre and post music therapy $p<$ 0.05

Results: There was no change on the severity of autism in pre and post test music therapy with 45,394 \pm 11.318 become $46.763 \pm 10.915(p=1,000)$. There was a significant difference on Early Social Communication Scale (ESCS) pre and post music therapy in group with mild-moderate autism from $2.194 \pm 0.496$ became $3.833 \pm 1.000(p=0.007)$.

Conclusions: Music therapy is a supporting therapy that can be given for autism child with mild to moderate autism to improve the ability of non-verbal communication
\end{abstract}

Keywords: Autism, Music Therapy, Ability of non-verbal communication.

\section{INTRODUCTION}

Autism is a syndrome or disorder of behavior, that begins at three years old. This syndrome affected the brain and made children difficult to communicate (both verbal and non verbal), decreased their communication skills, behavior disorder and social interaction. ${ }^{1-3,13-17,19}$

Autism is often found, boys are more than girls with the ratio of $4: 1$. It was reported that

Received in March 2012 and accepted for published in April 2012.

Correspondence address : Intan K Dewi, Email : intanfkundip@yahoo.com there were 5-6 out of 1000 children with autism also have behavioral disorder. ${ }^{2,4,5}$

The etiology is unknown, although it is believed that autism is related to the brain disfunction. It isn't known which part of the brain is involved, and how the process is. ${ }^{1,2,4,5}$

Music therapy is activity that use music and music activity to improve physical aspect, emotion, cognitive and social in child and adult that have disorder or certain disease. Children and adult with autism have difficulty in verbal and non verbal communication, social interaction, and playing activity. This disorders made children with autism difficult to communicate with other people and have relationship with others. ${ }^{6,7,18,20,21}$ 
In European country, music therapy has developed specifically through the psychodynamic and psychotherapy approach. A lot of clinical evidence on the effectiveness of music therapy to improve the ability to communicate, for instance in autism children (Howat 1995), in patient with neurological disorder such as Parkinson disease (Bony 1989), in emotional, physical and phsychological disorder patient (Davis 1999). The other research : The effect of music therapy for language skills in children with autism (K. Lindayani and Natalia J. 2001), Music therapy in the assessment and treatment of ASD (Autism Spectrum Disorder) and the effect of improvisation music therapy on joint attention behavior in autistic children (Gold C. Etc, 2006 and 2008), Use of song to promote independence in morning greeting routine for young children with autism (Kern $P$, 2007), Group music intervention reduce aggression and improves self-esteem in children with highly aggresive behaviour (Choi NA etc, 2008). ${ }^{6-12}$

The main outcome measure are Childhood Autism Rating Scale (CARS) to assess for severity category of autism (mild, moderate, severe) and Early Social Communication Scale (ESCS) to assess ability of non verbal communication with IJA (Initial Joint Attention) and Responding to Joint Attention (RJA). ${ }^{30,31}$

The purpose of this research to know music therapy effect to improve of the ability non verbal communication in autism child.

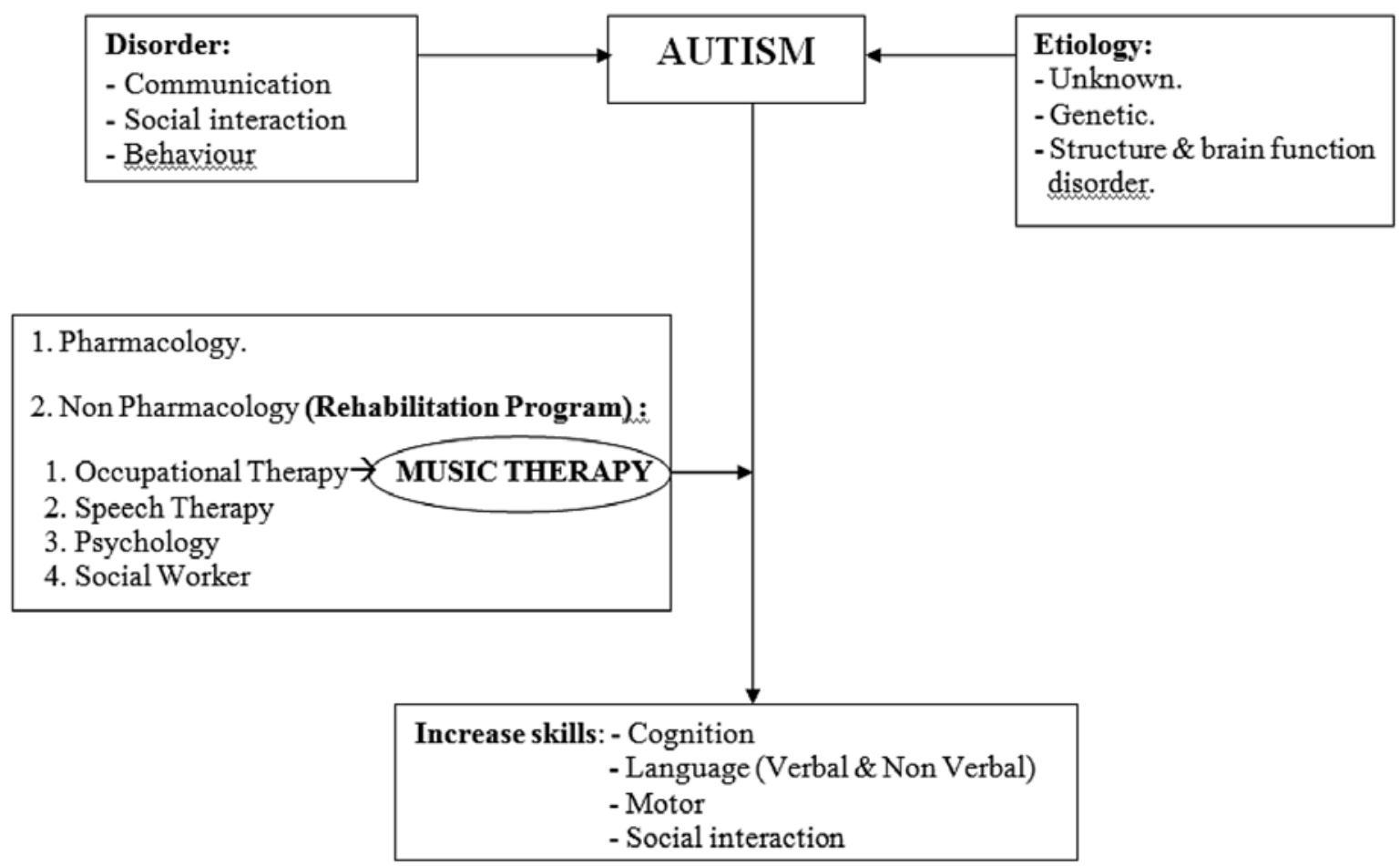

Figure 1. Conceptual frame of thought

Research hypothesis were (1) music therapy will improve the autism severity category by Scale/CARS scores, (2) music therapy will improve ESCS score.

\section{METHODS}

This prospective study used an music intervention, was a pre and post test design. This setting were in several places autism centre in Semarang city (Putra Mandiri, Cahaya Kirana, Yogasmara, Talitakum), from Desember 2009 until January 2010 until 15 session.

Inclusion criteria were autism patient aged 3-15 years old, had never been given music therapy previously, cooperative, and was able 
to follow instructions, agreed to involve in research with parental signed inform consent. Exclusion criteria were patient had hearing disorder, had specific syndrome like Down Syndrome, or rejected to join the research.
Drop out criteria were patient unable to finish all sessions of music therapy, fail to follow music therapy program 3 or more consecutive days, unable to comply research`s procedure.

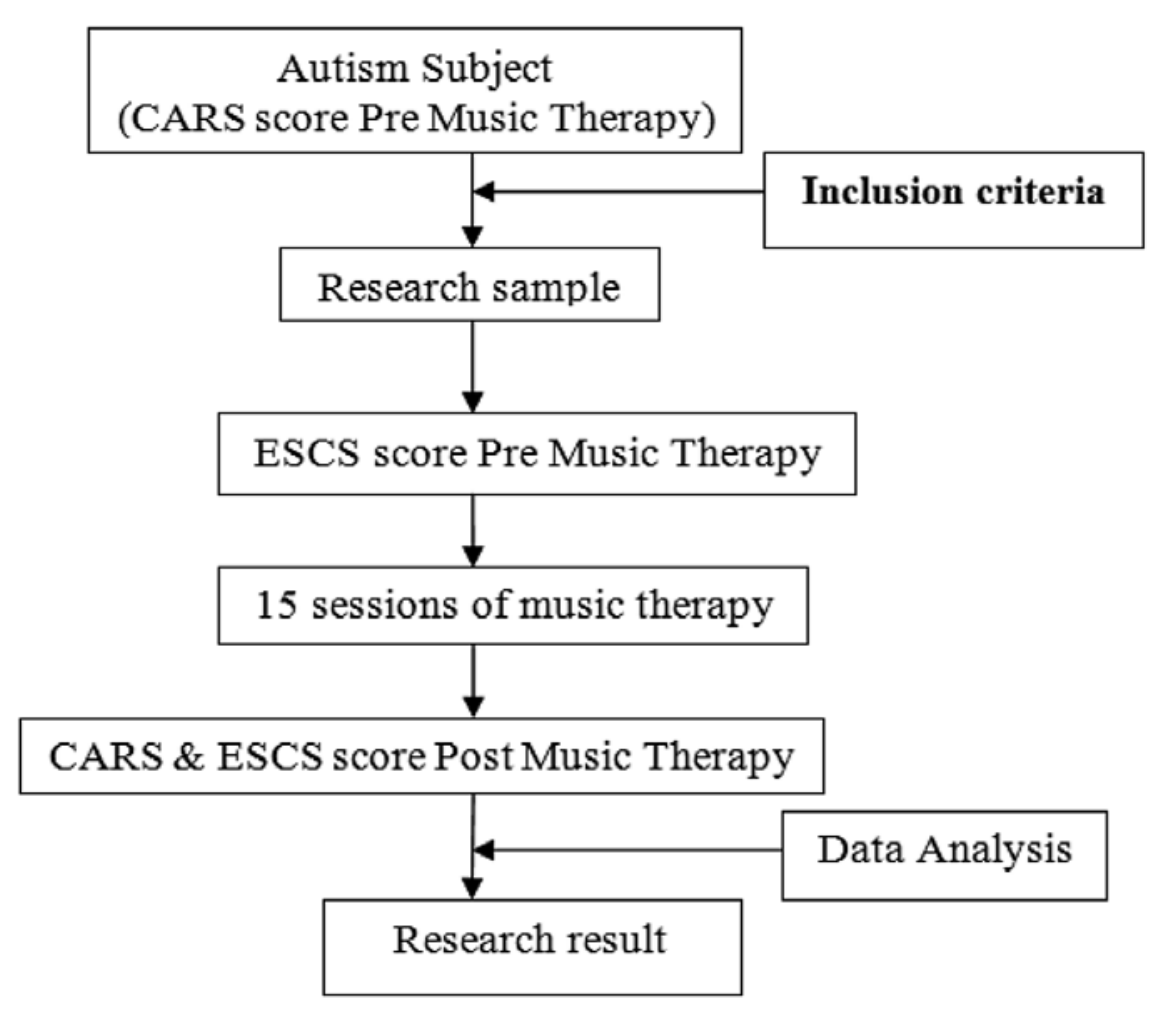

Figure 2. Research Protocol Schematic

All subject had music therapy by listening 3 children songs from tape recorder for 15 minutes daily. CARS and ESCS score assessment were conducted pre and post music therapy.

CARS score was used to assess children with autism, this score evaluates 15 dimensions of behavior on score of 1-4. Listed below are the 15 dimensions: (1) Relation to People, (2) Imitation, (3) Emotional Response, (4) Body use, (5) Object Use, (6) Adaptation to Change, (7) Visual Response, (8) Listening Response, (9) Taste, Smell, and Touch Respon and Use, (10) Fear or Nervousness, (11) Verbal Communication, (12) Non verbal Communication, (13) Activity Level, (14) Level and Consistency of Intellectual Response, (15) General Impression :1 - 1,5 is within normal limits, $2-2,5$ is mildly abnormal, $3-3,5$ is moderately abnormal, 4 is severely abnormal with total score : non autistic is $15-30$; mildmoderate autistic is $30-37$; severely autistic is 37-60.

The ESCS is a structured toy play assessment measuring non verbal communication skills in children with autism. We used the abridged version of the ESCS in this study. The ESCS provides frequencies of scores for two types of joint attention behavior: Initiating Joint Attention (IJA) refers to the frequency of child's eye contact, pointing and showing to initiate shared attention to objects or events and Responding to Joint Attention (RJA) refers to the child's skill in following the tester's line of regard and pointing gestures.

Descriptive statistic and homogeneity test was performed to see the change on CARS and ESCS score in pre and post music therapy. The significant difference $\mathrm{p}<0.05 .^{32,33}$ 
Table 1. Demographic Data

\begin{tabular}{|c|c|c|c|c|}
\hline \multirow{2}{*}{ Characteristic } & \multicolumn{2}{|c|}{ Group } & \multirow{2}{*}{$\mathrm{p}$} & \multirow{2}{*}{$\mathrm{t}$} \\
\hline & Mild-moderate Autism & Severe Autism & & \\
\hline Age (month) & 116.67 & 100.20 & 0.456 & 0.763 \\
\hline Sex & & & 1.000 & \\
\hline Boy & $8(88.9 \%)$ & $8(80 \%)$ & & \\
\hline Girl & $1(11.1 \%)$ & $2(20 \%)$ & & \\
\hline \multicolumn{5}{|l|}{ Autism centre } \\
\hline Putra Mandiri & $2(10.5 \%)$ & $1(5.3 \%)$ & & \\
\hline Cahaya Kirana & $4(21.1 \%)$ & $4(21.1 \%)$ & & \\
\hline Yogasmara & $2(10.5 \%)$ & $2(10.5 \%)$ & & \\
\hline Talitakum & $1(5.3 \%)$ & $3(15.8 \%)$ & & \\
\hline Education & & & 0.087 & \\
\hline Formal & $3(15.8 \%)$ & $0(0 \%)$ & & \\
\hline Non Formal & $6(31.6 \%)$ & $10(52.6 \%)$ & & \\
\hline
\end{tabular}

The study subjects were 19 autism children matched who met inclusion criteria and they were coming from several autism therapy centre in Semarang city on December 2009 to January 2010. In our study, we divided the subjects into two groups : mild- moderate autism (9 patient) and severe autism (10 patient). One patient from severe autism group could not accomplish the study because his parents went to other city.

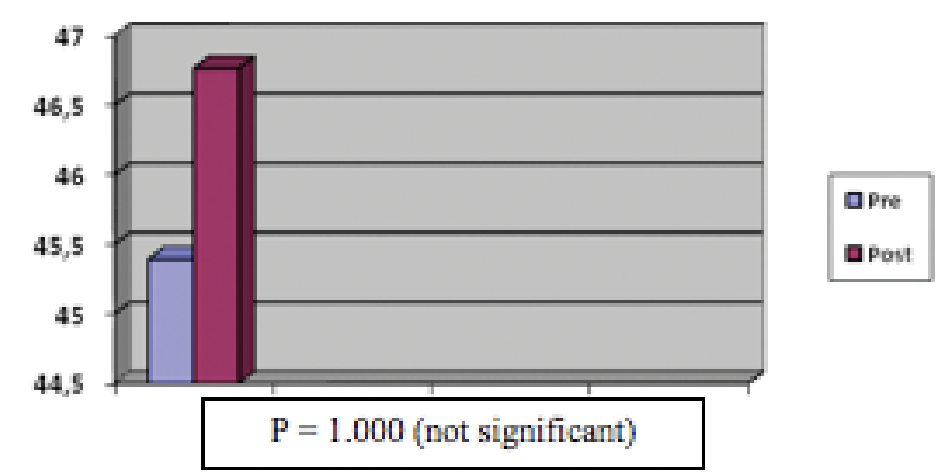

Figure 3. CARS score in Pre and Post Music Therapy

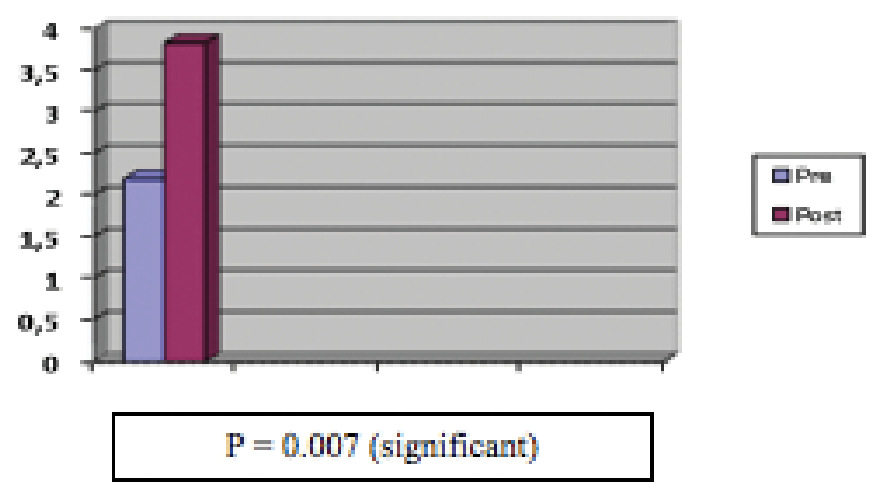

Figure 4. ESCS score in Pre and Post Music Therapy 


\section{DISCUSSION}

The CARS score was improved after music therapy, but it was not statistically significant. The severity of autism was changed to lower category. This result supports the theory that autism children can not be cured, but the symptom could be hidden, so that their social and behavior would be like an normal children. $27-30$

This ESCS score was improved significantly in with mild-moderate the subject after music therapy. This result was similar to may clinical evidences on the effectiveness of music therapy in improving ability to communicate. The ESCS result showed that music therapy is effective to improve Initial Joint Attention and Responding to Joint Attention. According to the theory, the symptom of mild-moderate autism could be hidden, but severe autism children still need special intervention. ${ }^{1,2,5-7,20,31}$

The effects of music therapy in autism children were shown in some changes, such as improving the ability to manage themselves and improving relationship with others, then they got an improved Quality Of Life(QOL). Music therapy can improve learning of cognitive process and could be used as a motivating factor,and enhance learning process. The melody and rhythm of the song could be used to help children in memorizing the song (for instance the alphabet, activity daily living and body part). ${ }^{7,20-22,24-26}$

Music therapy helps children to learn their environment, improve attention and concentration, and relieving stress as well. Music therapy can improve the ability of verbal and non- verbal communication, by listening children songs, the children will be asked to imitate the words and looking at the therapist face. Gold et al (2008) found that music therapy using instrumental music e.g piano, cymbal and colourful bells was more effective compared with playing session. ${ }^{10,20,23,24,28,29}$

The limitations of this study are CARS score assessment was performed by two different therapist, it might cause a bias in evaluation. Improvement of ESCS score in the autism children might be resulting from frequent face to face meetings with the therapist.

\section{CONCLUSIONS}

From this result, we conclude that there is no change on the severity category of autism in pre and post music therapy, there is a significant improvement on ESCS score post music therapy in group with mild-moderate autism, and there is no change on the ESCS score in group with severe autism post music therapy.

\section{REFERENCES}

1. Wulan M. Rehabilitasi Medik pada Autisme. In : Pelatihan Rehabilitasi Medik pada Pediatri (Autisme) di RSUP Dr Kariadi, 2002 December 18-20th. Semarang: Instalasi Rehabilitasi Medik RSUP Dr Kariadi ; 2002.

2. Tahitoe D. Rehabilitasi Medik pada Autisme. In : Proceeding Seminar Terapi Sensori integrasi, Okupasi dan Wicara untuk mengoptimalkan kemampuan anak Autis; 2002 July 13th. Semarang: P2GPA, Bagian Rehabilitasi Medik RS Telogorejo, Semarang Autism School. p.10-18.

3. Departemen Kesehatan RI. Pedoman Penggolongan dan Diagnosis Gangguan Jiwa di Indonesia. 3rd Edition. Jakarta; 1993.

4. Dalton R, Marc AF. Psikosis Pada Masa Anak. In : Wahab AS, editor . Ilmu Kesehatan Anak. 15th Editions. Jakarta:EGC, Penerbit Buku Kedokteran;1999.p.120-1.

5. Iwan F. Rehabilitasi Medik pada Autisme. Available at: http: //www.Autisme pada anak; cited on Dec 27th 2008.

6. DeLisa AJ, Donald CM, Martin MG. Rehabilitation Medicine Past, Present, and Future. In: Principles and Practice. 3rd edition. Philadelpia : JB Lippincot Company; 2000.p.886-915.

7. Djohan. Terapi Musik Teori dan Aplikasi. Cetakan II. Yogyakarta : Galangpress; 2006.

8. Kuwanto L, Natalia J. Pengaruh Terapi Musik Terhadap Ketrampilan Berbahasa pada anak Autis. Anima, Indonesian Psychological Journal. 2001;16(2):190-214.

9. Gold C, Wigram T. Music Therapy in the Assessment and Treatment of Austitic Spectrum Disorder: Clinical Application 
and research evidence. Pubmed; 2006

10. Gold C, Kim J, Wigram T. The effect of Improvisational Music Therapy on Joint Attention Behavior in Autistic Children : A Randomized Controlled Study. 2008;38:1758-66.

11. Kern P, Wolery M, Aldrige D. Use of Song to Promote Independence in Morning Greeting Routines for Young Children with Autism. The Original Paper, The Journal Autism Developmental Disorder. 2007;37: 1264-71

12. Choi NA, Soo LM, Sook JJ. Group Music Intervention Reduces Aggression and Improves Self-esteem in Children with Highly Aggressive Behavior: A Pilot Controlled Trial. Evidence-based Complementary and Alternative Medicine. 2008. Available at: $\mathrm{http}$ :// creativecommons. org.

13. Pusonegoro HD. Pandangan umum mengenai klasifikasi spectrum gangguan autistic dan kelainan susunan saraf pusat. In: Proceeding konferensi nasional autisme I; 2003 July 4th. Jakarta: PPDSKJI, IDAI, PERDOSSI ; 2003.p.1-7.

14. Hartono B. Aspek Neurologik Autisme infantil. In: Faradz SMH, Susilaningsih N, Purwoko Y. Seminar dan Workshop on Fragile-X Mental Retardation, Autism, and Related disorders; Semarang 2002 January 19th -23rd.

15. Ismed T. Kriteria Diagnosis Autisme dan Problematikanya. In: Faradz SMH, Susilaningsih N, Purwoko Y. Seminar dan Workshop on Fragile-X Mental Retardation, Autism, and Related disorders. Semarang; 2002 January 19th -23 rd.

16. Baird G, Cass H, Slonims V. Diagnosis of Autism. BMJ. 2003. Available from: http: // resources.bmj.com / bmj / subscribes.

17. Filipek PA, Accardo PJ, Aswhwal. Practical Parameter Screening and Diagnosis Autism. Special Article, Report of the quality Standards Subcomitte of The American Academy of Neurology and the child Neurology Society. AAN enterprises, Inc; 2000.

18. Widyawati I. Manajemen multidisiplin pada individu dengan Autistic Spectrum Disorder. Dalam: Makalah lengkap konferensi nasional Autisme I; 2003 July 2nd-4th. Jakarta: PPDSKJI, IDAI, PERDOSSI; 2003: 61-6.

19. American Psychiatric Association. Diagnostic and Statistical Mental Disorders 4th ed. Washington DC; 2000.

20. AMTA (American Music Therapy Association). Frequently Asked Questions About Music Therapy. Available from: http: //www.American Music Therapy Association.com.

21. Iesye W. Cerdas dengan Terapi Musik. Available from : http: //www.pdpersi.co.id. cited on: Sep 25, 2000.

22. Autism World. Music Therapy for children with Autism. Drury University in Missouri; 2007.

23. Irish Association of Creative Arts Therapists. Music Therapy. Available from: http: // www.iacat.ie.

24. Danuatmaja B. Terapi anak autis di rumah. Cetakan I. Jakarta: Puspa Swara; 2003.

25. Music Therapy: Information from Answers. com. Available from: http://www.anwers. com/topic/music-therapy.

26. Music Therapy- a therapeutic intervention for children with disabilities. Available from: http: //www. Family-friendly-fun. com/therapy/music.htm.

27. Music Therapy and Language for the Autistic Child. Available from: http://www. Autism.com/families/therapy.

28. Autism Disorder-Music Therapy Could Bring About A Significant Change. Available from: http : //www. Alternateheals.com/ music-therapy/music-therapy-and-autism. htm.

29. The Benefit of Music Therapy for Autism. http : //www. Enzinearticles.com.

30. Anderson S. CARS (Childhood Autism Rating Scale); 1998 September 12th.

31. Mundy P. ESCS (Early Social Communication Scales). University of Miami; 2003.

32. Notoatmodjo S. Metodologi Penelitian Kesehatan. Cetakan III. Jakarta : Rineka Cipta; 2005.

33. Sastroasmoro S, Ismael S. Dasar-dasar Metodologi Penelitian Klinis. Cetakan III. Jakarta : Sagung Seto; 2008 